\title{
Drought-associated changes in climate and their relevance for ecosystem experiments and models
}

\author{
H. J. De Boeck ${ }^{1}$ and H. Verbeeck ${ }^{2}$ \\ ${ }^{1}$ Research Group of Plant and Vegetation Ecology, Department of Biology, Universiteit Antwerpen (Campus Drie Eiken), \\ Universiteitsplein 1, 2610 Wilrijk, Belgium \\ ${ }^{2}$ Laboratory of Plant Ecology, Department of Applied Ecology and Environmental Biology, Faculty of Bioscience \\ Engineering, Ghent University, Coupure Links 653, 9000 Ghent, Belgium
}

Received: 22 November 2010 - Published in Biogeosciences Discuss.: 17 January 2011

Revised: 6 May 2011 - Accepted: 11 May 2011 - Published: 13 May 2011

\begin{abstract}
Drought periods can have important impacts on plant productivity and ecosystem functioning, but climatic conditions other than the lack of precipitation during droughts have never been quantified and have therefore not been considered explicitly in both experimental and modeling studies. Here, we identify which climatic characteristics deviate from normal during droughts and how these deviations could affect plant responses. Analysis of 609 years of daily data from nine Western European meteorological stations reveals that droughts in the studied region are consistently associated with more sunshine $(+45 \%)$, increased mean $\left(+1.6^{\circ} \mathrm{C}\right)$ and maximum $\left(+2.8^{\circ} \mathrm{C}\right)$ air temperatures and vapour pressure deficits that were $51 \%$ higher than under normal conditions. These deviations from normal increase significantly as droughts progress. Using the process-model ORCHIDEE, we simulated droughts consistent with the results of the dataset analysis and compared water and carbon exchange of three different vegetation types during such natural droughts and droughts in which only the precipitation was affected. The comparison revealed contrasting responses: carbon loss was higher under natural drought in grasslands, while increased carbon uptake was found especially in decidious forests. This difference was attributed to better access to water reserves in forest ecosystems which prevented drought stress. This demonstrates that the warmer and sunnier conditions naturally associated with droughts can either improve growth or aggravate drought-
\end{abstract}

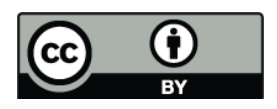

Correspondence to: H. J. De Boeck (hans.deboeck@ua.ac.be) related stress, depending on water reserves. As the impacts of including or excluding climatic parameters that correlate with drought are substantial, we propose that both experimental and modeling efforts should take into account other environmental factors than merely precipitation.

\section{Introduction}

Discrete climate events such as heat waves, droughts and storms, can have a disproportionate impact on ecosystems relative to the temporal scale over which they occur. A recent example is the European summer heat wave of 2003, which saw harvest losses surpass 10 billion dollars (Schär and Jendritzky, 2004), and which, together with the high number of premature human deaths (Vandentorren et al., 2004) served as a catalyst for increased public, political and scientific awareness (IPCC, 2007). Importantly, both the frequency and the intensity of extreme events is set to increase disproportionately under climate change (Meehl and Tebaldi, 2004), a direct consequence of the nature of probabilistic distributions (Schär et al., 2004). Research oriented towards (extreme) events rather than (gradual) trends, is therefore urgently needed (Jentsch et al., 2007). Simulating and modeling extreme events as realistically as possible is essential in correctly assessing the biotic responses to these events. Here, we assess the climatic characteristics of (atmospheric) droughts and look into consequences for plant systems. Droughts are reported to be increasing in frequency and intensity (Briffa et al., 2009), and are thought to have generally larger impacts on primary productivity than heat

Published by Copernicus Publications on behalf of the European Geosciences Union. 
Table 1. Description of the nine weather stations from which the meteorological record was used in our analyses.

\begin{tabular}{lllrr}
\hline weather station & country & coordinates & $\begin{array}{r}\text { station height } \\
\text { (m above sea level) }\end{array}$ & data series \\
\hline Basel & Switzerland & $47^{\circ} 33^{\prime} \mathrm{N}, 7^{\circ} 35^{\prime} \mathrm{E}$ & 316 & $1901-2004$ \\
De Bilt & The Netherlands & $52^{\circ} 06^{\prime} \mathrm{N}, 05^{\circ} 11^{\prime} \mathrm{E}$ & 3 & $1906-2008$ \\
Eelde & The Netherlands & $53^{\circ} 08^{\prime} \mathrm{N}, 06^{\circ} 35^{\prime} \mathrm{E}$ & 3 & $1957-2008$ \\
Genève & Switzerland & $46^{\circ} 15^{\prime} \mathrm{N}, 06^{\circ} 08^{\prime} \mathrm{E}$ & 420 & $1901-2004$ \\
Hannover & Germany & $52^{\circ} 27^{\prime} \mathrm{N}, 9^{\circ} 40^{\prime} \mathrm{E}$ & 59 & $1936-2008^{*}$ \\
Maastricht & The Netherlands & $50^{\circ} 55^{\prime} \mathrm{N}, 05^{\circ} 47^{\prime} \mathrm{E}$ & 114 & $1957-2008$ \\
Orléans & France & $47^{\circ} 58^{\prime} \mathrm{N}, 01^{\circ} 45^{\prime} \mathrm{E}$ & 125 & $1973-2008$ \\
Reims & France & $49^{\circ} 18^{\prime} \mathrm{N}, 04^{\circ} 01^{\prime} \mathrm{E}$ & 99 & $1973-2007$ \\
Saarbrcken & Germany & $49^{\circ} 12^{\prime} \mathrm{N}, 07^{\circ} 06^{\prime} \mathrm{E}$ & 322 & $1956-2008$ \\
\hline
\end{tabular}

* no data recorded in 1941, 1942 and 1945.

waves (Ciais et al., 2005). Research into plant responses to drought in ecological studies is done either by observation studies that rely on naturally occurring droughts (Ciais et al., 2005; Kljun et al., 2006) or by manipulation studies in which drought is imposed experimentally (e.g. Yang et al., 2000; Pfisterer and Schmid, 2002; da Costa et al., 2010). While naturally occurring droughts are, by definition, realistic, imposed droughts may not be. Indeed, there are obviously other factors affecting plant growth apart from water, such as temperature and radiation. If any of these environmental variables important to plant functioning were correlated with drought, they would need to be considered in drought manipulation experiments and modeling. To our knowledge, however, no attempt has been made to analyse whether such correlations exist, apart from general probabilistic characterisation (Serinaldi et al., 2009). Nevertheless, several studies have identified drought as an important instigator of heat waves (Fischer et al., 2007; Jaeger and Seneviratne, 2010; Hirschi et al., 2011). This is because the soil water status is connected to temperature and cloud formation via energy balance processes, and it therefore seems logical that droughts in their own right may be climatologically different from normal, although quantification is lacking. In this study, we first determine the average conditions during meteorological droughts (i.e. periods without significant precipitation) based on nine long term datasets throughout Western Europe. We then use these data as input in a process model (ORCHIDEE) to test with a simulation exercise whether significant differences in ecosystem carbon exchange exist between droughts when taking into account or not conditions other than lack of precipitation. In other words: how relevant is it to consider environmental conditions other than precipitation in drought research? The outcome has implications for both modeling and experimental studies.

\section{Material and methods}

\subsection{Historical droughts}

Quality controlled and publically available observational records (Klok and Klein-Tank, 2009) from nine Western European weather stations were used for our analyses (Table 1$)$. These records contain daily minimum $\left(T_{\min }\right)$, maximum $\left(T_{\max }\right)$ and mean $\left(T_{\text {mean }}\right)$ air temperatures, total sunshine hours, total precipitation and mean relative humidity $(\mathrm{RH})$. As a more relevant measure of air humidity for plants, the mean daily vapour pressure deficit (VPD) was calculated using the mean daily temperature and the mean daily relative humidity through the following standard formula (Jones, 1992):

$\mathrm{VPD}=(1-\mathrm{RH}) \times 0.611 e^{\frac{17.502 T_{\text {mean }}}{\mathrm{T}_{\text {mean }}+240.97}}$

In ecological experiments, drought is most commonly simulated by rainfall exclusion (usually by means of rainout shelters). We base our definition on the aforementioned experimental approach, and define drought as a number of consecutive days without significant precipitation (i.e. less than $1 \mathrm{~mm}$ per day, a quantity that is fully intercepted by most canopies) of which the minimum length is determined for each weather station separately. This station specific approach is essential as the probabilistic distribution, which varies across stations, determines what constitutes an extreme. For each weather station we calculated the minimum drought length $(x)$ based on the condition that the ratio of $x$-day running averages equal to zero (with precipitation considered zero on a day if it was below $1 \mathrm{~mm}$, see earlier) to the total number of days had to be equal or lower than 0.01 . This choice of cut-off ensured that we ended up with rare (i.e. extreme) events that were still statistically workable (i.e. enough data). We only consider the period from 15 March until 15 October as we are most interested in droughts during the growing season and as winter droughts are thought to be fundamentally different (Trenberth and Shea, 2005). Drought periods were 
each attributed to the month in which the bulk of their length was observed: a drought from 20 July until 15 August was labeled as an August drought. Drought days before 15 March and after 15 October were not considered.

We used SPSS 15.0 (SPSS Science, Woking, UK) for general linear model (GLM) univariate analysis, with climatological parameters (air temperatures, sunshine hours, relative humidity or vapour pressure deficit) as dependents and weather station, month and period type (= droughts, nondrought periods, start (first 10 days) or end (after day 10) of droughts) as fixed factors. The Games-Howell post-hoc test was used to separate multiple means. Data of relative humidity and vapour pressure deficit were transformed (square root, logarithmic or inverse) for normality. The significance threshold was 0.05 throughout all analyses.

\subsection{Simulation}

One full year was simulated with actual half-hourly meteorological data from three experimental sites part of the ICP Forest Level II and Fluxnet (Baldocchi et al., 2001; Gielen et al., 2010) networks: Brasschaat, Belgium $\left(51^{\circ} 18^{\prime} \mathrm{N}, 4^{\circ} 31^{\prime} \mathrm{E}\right)$, Vielsalm, Belgium $\left(50^{\circ} 18^{\prime} \mathrm{N}, 5^{\circ} 59^{\prime} \mathrm{E}\right)$ and Hesse, France $\left(48^{\circ} 40^{\prime} \mathrm{N}, 7^{\circ} 03^{\prime} \mathrm{E}\right)$. We used the data of 2004 , as this was an average year in terms of precipitation, temperature and sunshine compared to the $30-\mathrm{yr}$ average. A drought period of 26 days (the average drought length across our datasets, see later) was imposed starting 6 July (DOY 188) by setting all precipitation in this period to zero. A precipitation event of $17 \mathrm{~mm}$ of rain in $6 \mathrm{~h}$ (an arbitrary but actually recorded rain event in the Brasschaat database) was introduced after 26 days, to signal the end of the drought. For each site we used two datasets: one in which only the precipitation was altered during drought ("precipitation only drought"), and another in which we also adjusted minimum (09:00 p.m.-08:00 a.m.) and maximum (08:30 a.m.-08:30 p.m.) temperatures, relative humidity and radiation, to reflect the conditions naturally occurring during droughts ("natural drought"). Because radiation measurements were not available in most longterm datasets, we used sunshine hours instead. However, the model requires radiation as an input. Because there is a strong and linear relationship between sunshine hours and radiation $\left(R^{2}=0.80,28140\right.$ data points), it seems a fair approximation to consider the observed increase in sunshine hours during droughts ( $45 \%$, see later) and radiation equivalent. To avoid unnaturally bright days by adding $45 \%$ extra radiation to already sunny days, we averaged all half hourly radiation values during the drought to attain one average daily radiation course, and then added $45 \%$ to those values. The resulting "average day" was found to be somewhat less bright for every half hourly value than a fully sunny day during that period, and can therefore be considered realistic.

We used ORCHIDEE (Krinner et al., 2005), a processoriented integrated global land-surface model, to run the simulations. It simulates diurnal cycles of turbulent fluxes of
$\mathrm{CO}_{2}$, water and energy, while the ecosystem carbon and water dynamics (i.e. carbon allocation, plant respiration, growth, mortality, soil organic matter decomposition, water infiltration and runoff) are calculated at a daily time step. The standard ORCHIDEE equations are given by Ducoudré et al. (1993), Krinner at al. (2005), and Santaren et al. (2007). As in most global biogeochemical models, Plant Functional Types (PFTs) are used to classify vegetation at any particular site. ORCHIDEE simulates 13 PFTs at the globe scale, with all PFTs sharing the same equations but using different parameter values. Plant phenology is one exception, where PFT specific equations exist (Botta et al., 2000). For this study ORCHIDEE was run at local scale ("grid point mode") using the half-hourly meteorological forcing measured at the site. In this simulation exercise we used the standard ORCHIDEE parameterization of three PFTs that occur regularly in the region under consideration (Western Europe): C3 grassland, temperate broadleaf deciduous forest and temperate evergreen needle-leaf forest. We conducted a modelling experiment for these 3 PFTs at each of the 3 locations, and analysed daily ORCHIDEE outputs for carbon and water fluxes. We initialized biomass and soil carbon pools for each PFT to equilibrium values from a $2000 \mathrm{yr}$ long spin-up driven by cycling the $10 \mathrm{yr}$ available climate inputs.

Multiple interacting drought responses are modeled in ORCHIDEE. In the first place a direct response of canopy carbon and water exchange to meteorological drivers (temperature, radiation, VPD) is modeled through the photosynthesis (Farquhar et al., 1980) and stomatal conductance model (Ball et al., 1987). Secondly, simulated soil water availability affects stomatal conductance, transpiration, photosynthesis (Verbeeck et al., 2011), carbon allocation patterns (Friedlingstein et al., 1998) and heterotrophic respiration in the different litter and soil organic matter pools (Krinner et al., 2005). In the standard ORCHIDEE model, soil hydrology is simulated using two reservoirs ("double bucket model"). The soil water availability for the vegetation is calculated based on an exponential root profile. The PFT specific parameter values of the above described equations induce a different response to drought for each of the PFTs used in this study (e.g. photosynthetic capacity, rooting profile and allocation are different for grassland compared to temperate deciduous forest).

The ORCHIDEE model has been tested intensively at both site level (e.g. Krinner et al., 2005; Schwalm et al., 2010) and continental scale (e.g. Vetter et al., 2008). Moreover, the model has been applied and evaluated for drought events of different scales in space and time (e.g. Ciais et al., 2005; Jung et al., 2007; Reichstein et al., 2007; Gerten et al., 2008; Luo et al., 2008; Vetter et al., 2008; Schwalm et al., 2010). 

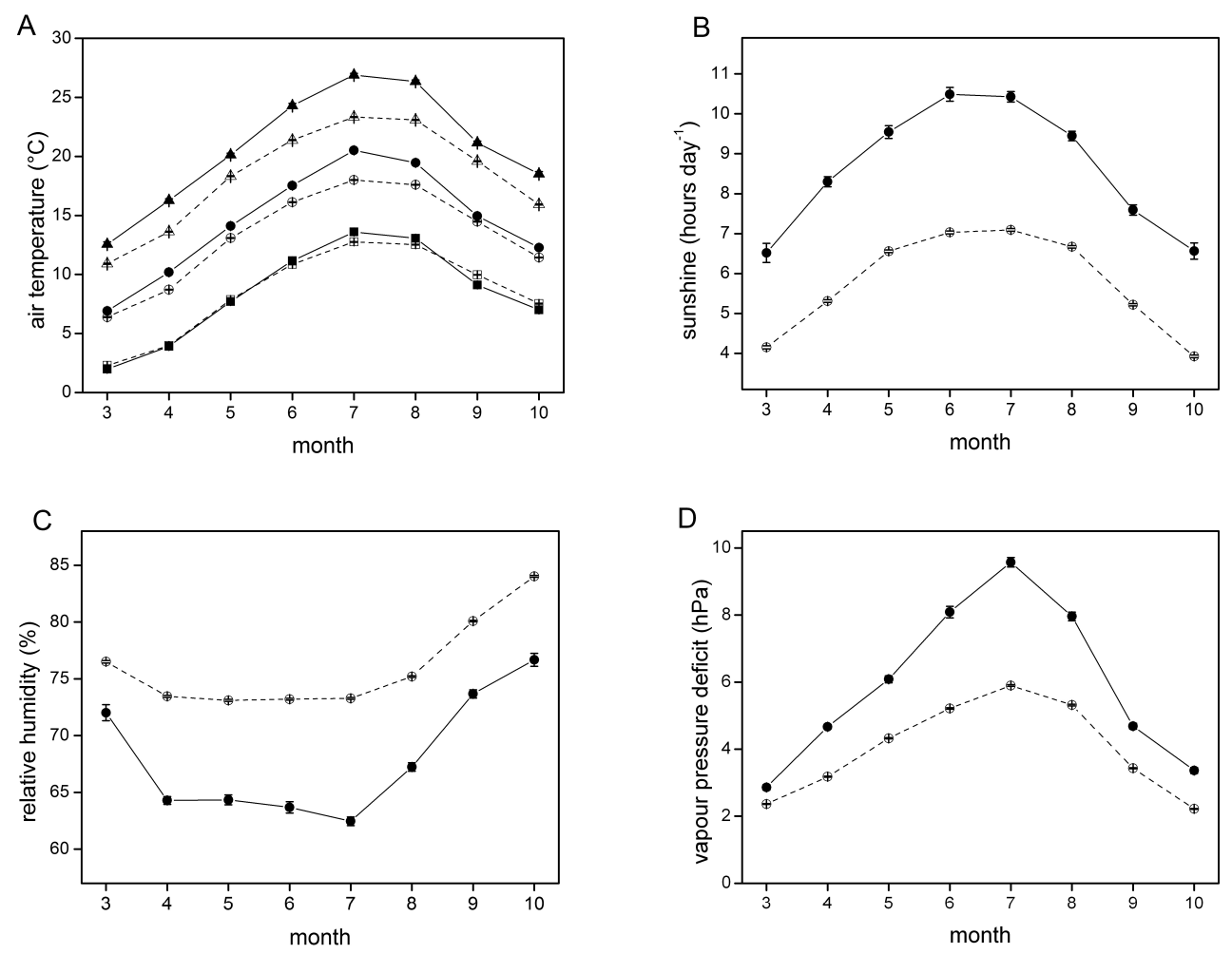

Fig. 1. Meteorological data from nine weather stations throughout Western Europe (details: see Table 1). Averages \pm standard errors per month from 15 March until 15 October, during (black) and outside (white) of droughts (definition: see text). (A) minimum (squares), mean (circles) and maximum (triangles) air temperatures, (B) hours of daily sunshine, (C) daily average relative humidity, (D) calculated vapour pressure deficit from average air temperatures and relative humidity. Points are connected for clarity.

\section{Results}

\subsection{Historical droughts}

In the records of the nine Western European weather stations we identified a total number of 227 droughts which lasted nearly 26 days on average, a length that was fairly constant across stations. Minimal air temperature anomalies (calculated as $\Delta T_{\min }$, the deviation from the average $T_{\min }$, calculated separately for each day of the year) during droughts did generally not deviate significantly from normal (Table 2). However, there was an interaction with month $(p<0.001)$, caused by a slight positive $\Delta T_{\min }$ during summer (Fig. 1a). Droughts were furthermore characterised by higher mean $\left(+1.6^{\circ} \mathrm{C}, p<0.001\right)$ and maximum temperatures $\left(+2.8^{\circ} \mathrm{C}\right.$, $p<0.001)$, an increase that was observed throughout the growing season and in all weather stations, although it fluctuated between months $(p<0.001)$. Droughts were not only found to be warmer than average, they were also markedly sunnier, with $45 \%$ more sunshine hours recorded $(p<0.001$, Fig. 1b). Relative differences (not shown) indicate that increases in sunshine duration were smallest in summer, explaining the significant interaction with month $(p<0.001)$. Relative humidity was reduced by on average $12 \%$ during droughts $(p<0.001$, Fig. 1c), with the strongest de- creases observed during late spring and early summer. Finally, droughts coincided with large increases of the average vapour pressure deficit $(+51 \%, p<0.001)$, with some variations between months and stations (Table 2, Fig. 1d) but without clear trends. We tested whether drought characteristics are similar across the full drought period, by distinguishing between the start of the drought (the first 10 days) and the end of the drought (from day 11 until the first significant precipitation event). We found, perhaps not surprisingly, very significant effects for all tested parameters $(p<0.001$ in all post-hoc tests), with the end of drought periods being warmer, sunnier and drier than the onset (Fig. 2). This robust trend was observed in all stations and in all months.

\subsection{Simulation}

Our model runs show that a natural 26-day drought had consistent positive effects on the net carbon uptake in deciduous broadleaf forests but negative effects in grasslands, when compared to a precipitation only drought (Fig. 3a). Differences between both drought types were marginal in evergreen forests. Photosynthetic uptake (GPP) was higher under natural compared to precipitation only drought in both forest types, but lower in grasslands (Fig. 3b). Likewise, ecosystem respiration was increased in forests, but not consistently 
Table 2. Overview of meteorological conditions for all nine weather stations used in our analyses, from 15 March until 15 October. Anomalies $(\Delta)$ during droughts were calculated for each day and then averaged: i.e. daily values (temperatures, sunshine hours, etc.) during droughts were compared to the average (av) values (also shown) during those specific days of the year. See text for definitions.

\begin{tabular}{|c|c|c|c|c|c|c|c|c|c|c|c|c|c|}
\hline & $\begin{array}{l}\text { data } \\
\text { (years) }\end{array}$ & $\begin{array}{l}\text { av } T_{\min } \\
\left({ }^{\circ} \mathrm{C}\right)\end{array}$ & $\begin{array}{l}\Delta T_{\min } \\
\left({ }^{\circ} \mathrm{C}\right)\end{array}$ & $\begin{array}{l}\text { av } T_{\text {mean }} \\
\left({ }^{\circ} \mathrm{C}\right)\end{array}$ & $\begin{array}{l}\Delta T_{\text {mean }} \\
\left({ }^{\circ} \mathrm{C}\right)\end{array}$ & $\begin{array}{l}\text { av } T_{\max } \\
\left({ }^{\circ} \mathrm{C}\right)\end{array}$ & $\begin{array}{l}\Delta T_{\max } \\
\left({ }^{\circ} \mathrm{C}\right)\end{array}$ & $\begin{array}{l}\text { av sunshine } \\
\text { (hours day }{ }^{-1} \text { ) }\end{array}$ & $\begin{array}{l}\Delta \text { sunshine } \\
(\%)\end{array}$ & $\begin{array}{l}\text { av RH } \\
(\%)\end{array}$ & $\begin{array}{l}\Delta \mathrm{RH} \\
(\%)\end{array}$ & $\begin{array}{l}\text { av VPD } \\
\mathrm{hPa}\end{array}$ & $\begin{array}{l}\Delta \mathrm{VPD} \\
(\%)\end{array}$ \\
\hline Basel & 104 & 10.2 & -0.05 & 15.0 & 1.44 & 20.9 & 2.55 & 6.1 & 44.3 & 74.6 & -10.0 & 4.70 & 42.2 \\
\hline De Bilt & 103 & 8.3 & 0.26 & 13.2 & 1.63 & 18.1 & 2.83 & 5.9 & 43.1 & 77.3 & -10.6 & 3.67 & 52.3 \\
\hline Eelde & 52 & 8.5 & 0.75 & 13.3 & 2.22 & 18.2 & 3.68 & 6.4 & 50.7 & 82.6 & -13.3 & 3.51 & 62.1 \\
\hline Genève & 104 & 9.4 & 0.07 & 14.5 & 1.06 & 19.7 & 1.64 & 7.1 & 37.1 & 70.4 & -8.3 & 5.29 & 28.3 \\
\hline Hannover & 70 & 8.4 & -0.61 & 13.5 & 1.13 & 18.5 & 2.27 & 6.0 & 43.2 & 75.0 & -11.8 & 4.21 & 48.2 \\
\hline Maastricht & 52 & 9.6 & 1.14 & 14.1 & 2.94 & 18.9 & 4.40 & 5.3 & 62.8 & 74.0 & -13.1 & 4.54 & 70.3 \\
\hline Orléans & 36 & 9.5 & 0.31 & 14.8 & 0.00 & 20.6 & 2.40 & 6.8 & 37.8 & 71.5 & -7.4 & 5.42 & 29.2 \\
\hline Reims & 35 & 9.5 & -0.11 & 15.4 & 1.57 & 21.1 & 2.43 & 6.8 & 37.1 & 73.7 & -12.3 & 5.04 & 50.9 \\
\hline \multirow[t]{2}{*}{ Saarbrcken } & 53 & 9.3 & 0.66 & 13.8 & 2.13 & 18.6 & 3.11 & 6.3 & 51.6 & 73.8 & -17.9 & 4.63 & 71.0 \\
\hline & 609 & 9.2 & 0.27 & 14.2 & 1.57 & 19.4 & 2.81 & 6.3 & 45.3 & 74.8 & -11.6 & 4.56 & 50.5 \\
\hline
\end{tabular}

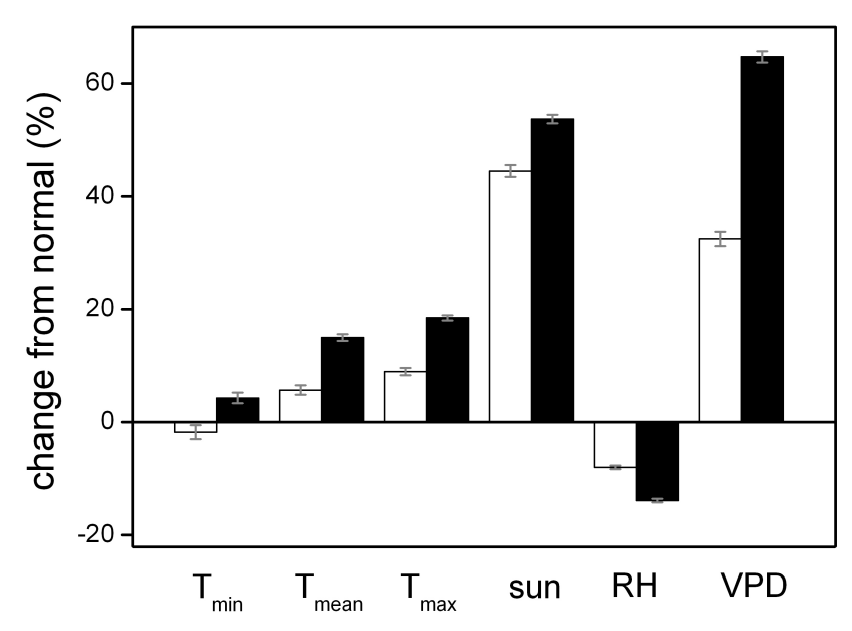

Fig. 2. Comparison of meteorological data at nine weather stations throughout Western Europe (details: see Table 1) the first 10 days of a drought (definition: see text), white bars, with the period 11th day of a drought until the drought end, black bars. The average relative change to normal conditions (all data excluding droughts) is depicted \pm standard errors.

so in grasslands (Fig. 3c). The increase in evapotranspiration, in response to higher VPD and increased radiation, is lower in grasslands than in forests (Fig. 3d), which indicates that accessible water reserves were more plentiful in forests, allowing plants to keep stomates open (longer). The daily course of net carbon uptake reveals that also in grasslands, natural droughts stimulated NEE compared to precipitation only droughts the first few days (Fig. 4). This response was then reversed, further hinting that grasslands suffered from earlier depletion of water reserves than forests. Towards the end of the drought, forests also exhibited a reversed response, signaling that conditions in natural droughts were gradually turning less favourable than in precipitation only droughts.

\section{Discussion}

\subsection{Meteorological conditions}

Droughts are gradual events that build up over the course of weeks or months and can be accelerated by high temperatures (De Boeck et al., 2011), as is sometimes expressed by using the Palmer Drought Severity Index (e.g. Briffa et al., 2009). Here, we focused on droughts like they are usually considered in experimental and modeling studies, namely those periods that lack significant precipitation. Our analysis of nine long-term meteorological databases showed that such drought periods, at least in Western Europe, are typically also warm and sunny and encompass higher-than-average demands on transpiration. This was observed throughout the growing season, although deviations from normal conditions were more pronounced in some months. We believe that the general meteorological characteristics of droughts reported here will be upheld even if the definition would change to include processes on longer timescales (i.e. less distinct periods). As a test, we compared conditions from 15 March-15 October 2003 to normal, and found also here more sunshine, higher temperatures, lower RH and higher VPD, although the anomalies where less outspoken than for the precipitation-free droughts focused on here (data not shown). Warm, sunny and dry conditions also prevailed during heat waves in the same region (De Boeck et al., 2010). This is consistent with a global study by Trenberth and Shea (2005), in which they reported that temperature and precipitation generally co-vary positively in winter and negatively in summer, and should therefore not be interpreted as stand-alone parameters. At the basis are fairly simple physical laws: dry soils cause more energy dissipation in the form of sensible heat, which generally leads to less convective cloud formation, resulting in more sunshine and consequently higher daytime temperatures which in turn accelerate soil drying (Vautard et al., 2007; Fischer et al., 2007b). The same cascade also explains why droughts get progressively 

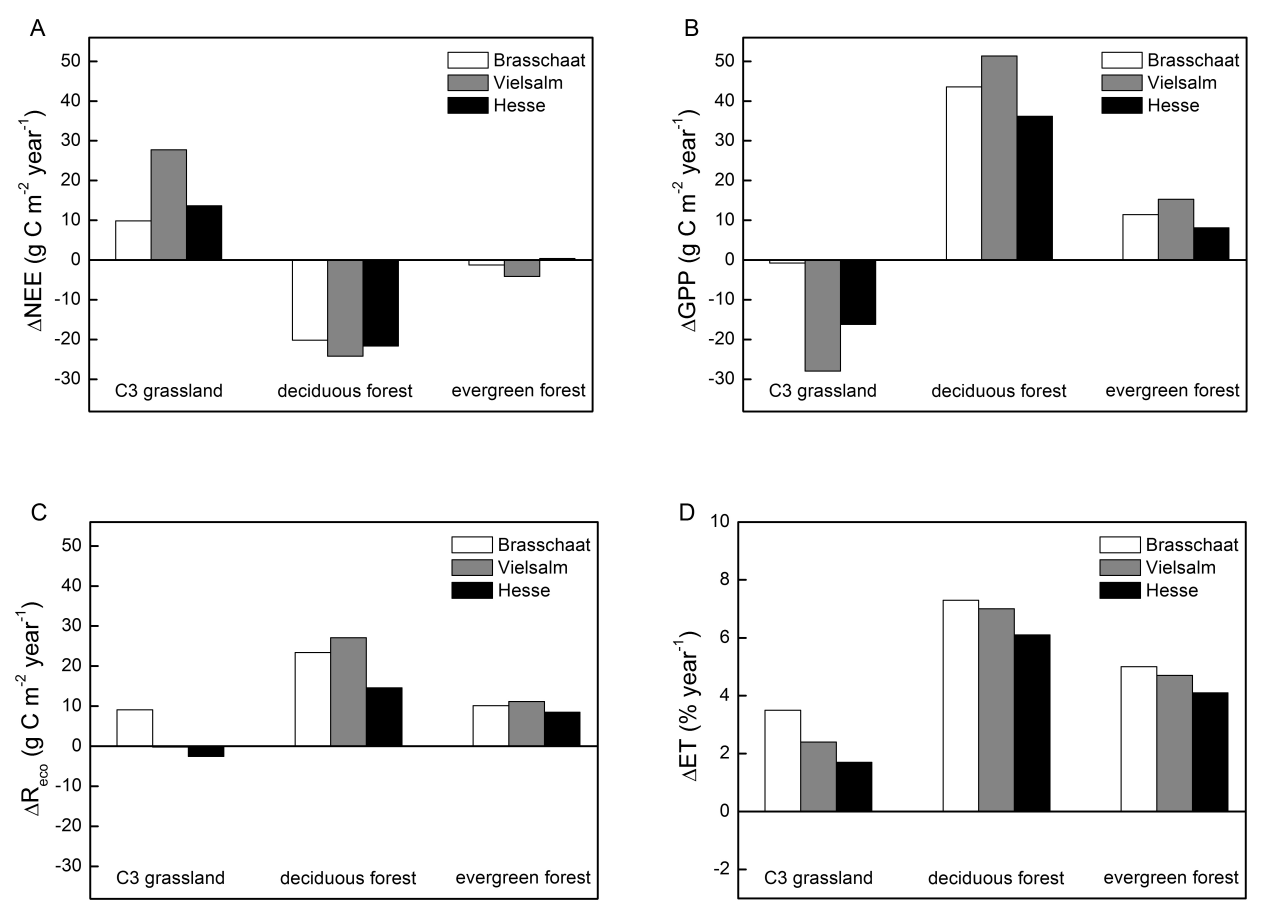

Fig. 3. Results from the ORCHIDEE model runs of carbon and water fluxes: (A) net ecosystem exchange, (B) gross primary production and (C) ecosystem respiration, and (D) evapotranspiration. Output for different plant functional types in three Fluxnet sites: differences shown between 'natural drought' and 'precipitation only drought' across the entire year (2004). See text for details.

warmer and sunnier, as we demonstrated. Our finding in a previous study (De Boeck et al., 2010) that heat waves are characterised by significantly less $(-78 \%)$ precipitation than normal and that they most often occur after a period of substandard rainfall should be regarded in the same light. New model simulations reinforce the notion of a slow build-up of heat via drought, with heat waves projected to become more intense at the end of summer through progressive soil moisture depletion effects (Fischer and Schär, 2009). Conil et al. (2009) argue that soil moisture data can therefore be used to improve seasonal climate forecasts.

\subsection{Plant responses}

With a widely used process model we tested whether taking into account the conditions we found to be naturally associated with droughts could significantly affect plant carbon and water fluxes. This is an important consideration, as correlations between precipitation-free periods and sunshine, temperature and relative humidity - all variables important to plant growth and ecosystem functioning - have never been quantified previously. As a consequence, they are not explicitly considered in drought simulation, both experimentally and in models. The results from the ORCHIDEE model runs suggest that natural droughts increased net carbon uptake substantially in deciduous forests, marginally in evergreen forests and led to a net loss of carbon in grasslands when compared to droughts with no changes in environ- mental conditions other than precipitation. Natural drought conditions also gave rise to important evapotranspiration increases, likely mostly in response to the $50 \%$ higher VPD (Beer et al., 2007). This implies that ecosystems become more vulnerable to recurrent droughts, and that the depletion of water reserves may be underestimated by using the precipitation only approach to droughts. The generally shallowrooted grasslands only very briefly (days) responded positively to natural droughts, whereas this positive response lasted much longer (weeks) in forests. This implies that trees could largely avoid drought stress by tapping into deeper soil water reserves (Zeng, 2001), which is captured by the model via PFT specific rooting profiles (Krinner et al., 2005). In addition, forests have other mechanisms to overcome dry periods which are not included in the model simulations: e.g. stem storage water use (Verbeeck et al., 2007) or hydraulic lift (Caldwell et al., 1998). These findings are in agreement with an analysis of flux tower measurements across Europe by Teuling et al. (2010), which concluded that grasslands use up the available water significantly faster than forests in case of drought.

Our modelling results support the hypothesis that, as long as plants have adequate water supply, the conditions during natural droughts are generally more favourable than average, at least in temperate systems: (i) increased radiation generally stimulates photosynthesis, and (ii) higher daytime temperatures and more sunshine could raise leaf temperatures closer to metabolic optima (Larcher, 2003), which 


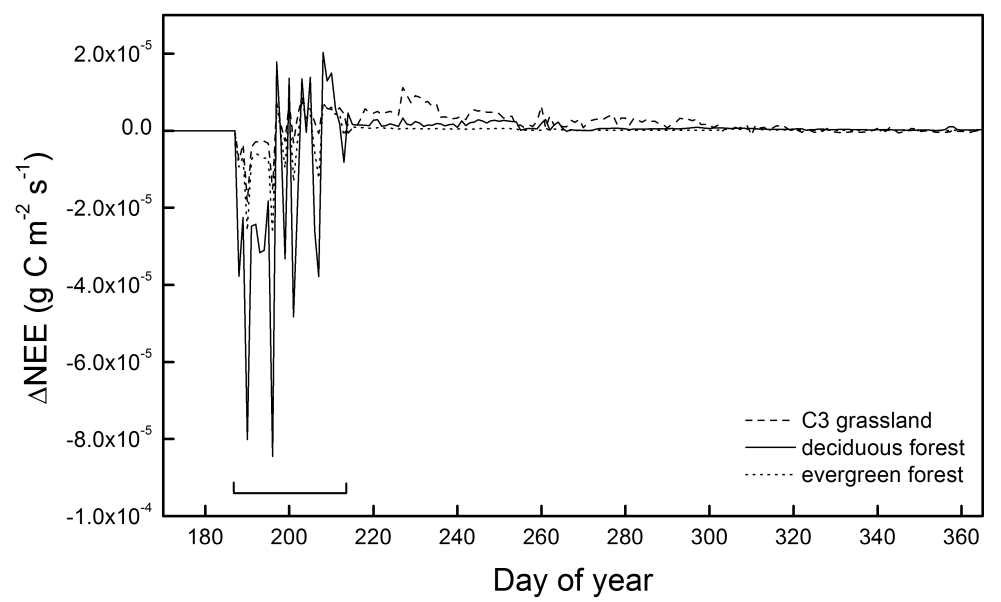

Fig. 4. Yearly course of net ecosystem exchange for three different plant functional types modeled with ORCHIDEE: differences between "natural drought" and "precipitation only drought" for the modelling experiment using the meteorological data of the Vielsalm site. Drought period (day 188-213) indicated.

is especially probable during spring and autumn, while increased transpiration (a consequence of higher VPD and radiation) would largely avoid high air temperature from leading to heat stress (through high leaf temperature) in summer (De Boeck et al., 2011). The model outputs indeed revealed increased net carbon uptake in summer under natural droughts until water reserves were depleted (Fig. 4), while an observational study by Delpierre et al. (2009) showed that gross primary productivity during the long 2007 spring drought was the maximum ever recorded for that period in Europe. Positive responses may be somewhat less distinct in autumn, as warming has been reported to stimulate respiration more than photosynthesis in this season (Piao et al., 2008).

If, on the other hand, the water reserves have been depleted or cannot be reached, the environmental conditions prevalent during natural droughts could serve as stress-amplifiers: (i) stomatal closure as a response to soil drought and high VPDs would increase leaf temperatures and may lead to heat stress (De Boeck et al., 2011), especially in combination with high radiation and increased maximum temperatures, (ii) high-light stress may be exacerbated by drought (Chaves et al., 2003) resulting in photoinhibitation and in extreme cases even photodamage (Larcher, 2003), and (iii) increased temperatures, radiation and VPD could speed up the drought by increasing evapotranspiration (cf. De Boeck et al., 2011). Indeed, the water-limited grasslands in our simulation responded more negatively to natural than to precipitation only drought, while both forest types exhibited the opposite response as they were not (yet) limited by water. This illustrates that, depending on the water status, the conditions during natural droughts serve as a catalyst for either positive or negative effects on plant growth. It is worth noting that forests too appeared to start experiencing the negative effects of natural droughts towards the end of the 26day drought. Forests may therefore be primarily sensitive to either very long droughts or repeated droughts that gradually deplete even the deep soil water reserves (such as happened in the 2003 European drought). Negative effects in temperate forests would therefore be concentrated at the end of summer (Granier et al., 2007), while grasslands could be affected by droughts throughout the growing season. Diverging responses may not be restricted only to ecosystem types (Teuling et al., 2010) but could also occur within the ecosystem itself as some plants' root systems are deeper and can tap into the water table during droughts while shallower rooted species are already experiencing drought stress (Padilla and Pugnaire, 2007; Gilgen et al., 2010). In combination with the catalysing properties of natural droughts, this suggests that the competitive differences between species during droughts may have been underestimated in experiments and models thus far.

We propose that our results should be considered in both modeling and experimental studies. Models could fairly easily incorporate drought-related environmental conditions. This is already implicitly included in models that base conditions on stochastic weather generators, because these create synthetic series of daily weather from historical data intended to be similar to those observed in historical weather (e.g. Apipattanavis et al., 2010). Experiments could explicitly mimic natural drought conditions by means of infrared heaters, which both increase leaf temperatures and vapour pressure differences (Kimball, 2005; De Boeck et al., 2010), and solar lamps (cf. Deckmyn et al., 1994). Unfortunately, these techniques are currently only suited for small-statured systems. Otherwise, any drought experiment should avoid as much as possible light attenuation (Svejcar et al., 1999; Charles and Dukes, 2009), increased relative humidity (Beier et al., 2004) and night-time warming (Lucas et al., 2008; Charles and Dukes, 2009), for example by using retractable rainout shelters (Beier et al., 2004). 


\section{Conclusions}

Using long-term observational records, we have shown that precipitation-free periods throughout Western Europe are associated with notable changes in sunshine duration $(+45 \%)$, mean $\left(+1.6^{\circ} \mathrm{C}\right)$ and maximum $\left(+2.8^{\circ} \mathrm{C}\right)$ air temperatures and demands on transpiration (VPD $+51 \%$ ), and that these changes are exacerbated as the drought progresses. Model runs based on these data suggest that such natural droughts could either stimulate growth or suppress it compared to precipitation only droughts, depending on the plants' access to water reserves. This can have profound implications on the outcome of drought studies, and we suggest that new research efforts on drought impacts, both experimental and modeled, will provide more realistic and relevant results if they incorporate such naturally occurring conditions. Finally, droughts and their characteristics may vary in different geographical areas, and assessments such as this should therefore be made for each region separately.

Acknowledgements. H. J. De Boeck is a post-doctoral research associate of the Fund for Scientific Research - Flanders. We thank the KNMI, Marc Aubinet and André Granier for use of their data record, the ORCHIDEE team at LSCE (Gif-sur-Yvette, France), M. Campioli and B. Gielen for advice, and three reviewers for helpful comments.

Edited by: G. Wohlfahrt

\section{References}

Apipattanavis, S., Bert, F., Podesta, G., and Rajagopalan, B.: Linking weather generators and crop models for assessment of climate forecast outcomes, Agr. Forest. Meteorol., 150, 166-174, 2010.

Baldocchi, D., Falge, E., Gu, L., Olson, R., Hollinger, D., Running, S., Anthoni, P., Bernhofer, Ch., Davis, K., Evans, R., Fuentes, J., Goldstein, A., Katul, G., Law, B., Lee, X., Mahli, Y., Meyers, T., Munger, W., Oechel, W., Paw U, K. T., Pilegaard, K., Schmid, H. P., Valentini, R., Verma, S., Vesala, T., Wilson, K., and Wofsy, S.: FLUXNET: a new tool to study the temporal and spatial variability of ecosystem-scal carbon dioxide, water vapour, and energy flux densities, B. Am. Meteorol. Soc., 82, 2415-2434, 2001.

Ball, J. T., Woodrow, I. E., and Berry J. A.: A model predicting stomatal conductance and its contribution to the control of photosynthesis under different environmental conditions, edited by: Biggens, J., Progress in Photosynthesis Research, vol. IV, IV.5.221., 1987.

Beer, C., Reichstein, M., Ciais, P., Farquhar, G. D., and Papale, D.: Mean annual GPP of Europe derived from its water balance, Geophys. Res. Lett., 34, L05401, doi:10.1029/2006GL029006, 2007.

Beier, C., Emmett, B., Gundersen, P., Tietema, A., Penuelas, J., Estiarte, M., Gordon, C., Gorissen, A., Llorens, L., Roda, F., and Williams, D.: Novel Approaches to Study Climate Change Effects on Terrestrial Ecosystems in the Field: Drought and Passive Nighttime Warming, Ecosystems, 7, 583-597, 2004.
Botta, A., Viovy, N., Ciais, P., and Friedlingstein, P.: A global prognostic scheme of leaf onset using satellite data, Global Change Biol., 6, 709-726, 2000.

Briffa, K. R., van der Schrier, G., and Jones, P. D.: Wet and dry summers in Europe since 1750: evidence of increasing drought, Int. J. Climatol., 29, 1894-1905, 2009.

Caldwell, M. M., Dawson, T. E., and Richards, J. H.: Hydraulic lift: consequences of water efflux from the roots of plants, Oecologia, 113, 151-161, 1998.

Charles, H. and Dukes, J. S.: Effects of warming and altered precipitation on plant and nutrient dynamics of a New England salt marsh, Ecol. Appl., 19, 1758-1773, 2009.

Chaves, M. M., Maroco, J. P., and Pereira, J. S.: Understanding plant responses to drought - from genes to the whole plant, Funct. Plant Biol., 30, 239-264, 2003.

Ciais, P., Reichstein, M., Viovy, N., Granier, A., Ogee, J., Allard, V., Aubinet, M., Buchmann, N., Bernhofer, C., Carrara, A., Chevallier, F., De Noblet, N., Friend, A. D., Friedlingstein, P., Grunwald, T., Heinesch, B., Keronen, P., Knohl, A., Krinner, G., Loustau, D., Manca, G., Matteucci, G., Miglietta, F., Ourcival, J. M., Papale, D., Pilegaard, K., Rambal, S., Seufert, G., Soussana, J. F., Sanz, M. J., Schulze, E. D., Vesala, T., and Valentini, R.: Europe-wide reduction in primary productivity caused by the heat and drought in 2003, Nature, 437, 529-533, 2005.

Conil, S., Douville, H., and Tyteca, S.: Contribution of realistic soil moisture initial conditions to boreal summer climate predictability, Clim. Dynam., 32, 75-93, 2009.

Da Costa, A. C. L., Galbraith, D., Almeida, S., Portela, B. T. T., Da Costa, M., De Athaydes Silva Junior, J., Braga, A. P., De Gonçalves, P. H. L., De Oliveira, A. A., Fisher, R., Phillips, O. L., Metcalfe, D. B., Levy, P., and Meir, P.: Effect of 7 yr of experimental drought on vegetation dynamics and biomass storage of an eastern Amazonian rainforest, New Phytol., 187, 579-591, 2010.

De Boeck, H. J., Dreesen, F. E., Janssens, I. A., and Nijs, I.: Climatic characteristics of heat waves and their simulation in plant experiments, Global Change Biol., 16, 1992-2000, 2010.

De Boeck, H. J., Dreesen, F. E., Janssens, I. A., and Nijs, I.: Wholesystem responses of experimental plant communities to climate extremes imposed in different seasons, New Phytol., 189, 806817, 2011.

Deckmyn, G., Martens, C., and Impens, I.: The importance of the ratio UV-B/PAR during leaf development as determining factor of plant sensitivity to increased UV-B irradiance: effects on growth, gas-exchange and pigmentation of bean plants (Phaseolus vulgaris L). Plant Cell Environ., 17, 295-301, 1994.

Delpierre, N., Soudani, K., Francois, C., Kostner, B., Pontailler, J. Y., Nikinmaa, E., Misson, L., Aubinet, M., Bernhofer, C., Granier, A., Grunwald, T., Heinesch, B., Longdoz, B., Ourcival, J.-M., Rambal, S., Vesala, T., and Dufrene, E.: Exceptional carbon uptake in European forests during the warm spring of 2007: a data-model analysis, Global Change Biol., 15, 14551474, 2009.

Ducoudré, N. I.: SECHIBA, a new set of parameterizations of the hydraulic exchanges at the land-atmosphere interface within the LMD atmospheric general circulation model, J. Clim., 6, 248273, 1993.

Farquhar, G. D., von Caemmerer, S., and Berry J. A.: A biochemical model of photosynthetic $\mathrm{CO} 2$ assimilation in leaves of $\mathrm{C} 3$ 
species, Planta, 149, 78-90, 1980.

Fischer, E. M., Seneviratne, S. I., Vidale, P. L., Lüthi, D., and Schär, C. Soil moisture-atmosphere interactions during the 2003 European summer heatwave, J. Clim., 20, 5081-5099, 2007.

Fischer, E. M., Seneviratne, S. I., Lüthi, D., and Schär, C.: Contribution of land-atmosphere coupling to recent European summer heat waves, Geophys. Res. Lett., 34, L06707, doi:10.1029/2006GL029068, 2007b.

Fischer, E. M. and and Schär, C.: Future changes in daily summer temperature variability: driving processes and role for temperature extremes, Clim. Dynam., 33, 917-935, 2009.

Friedlingstein, P., Joel, G., Field, C. B., and Fung I. Y.: Toward an allocation scheme for global terrestrial carbon models, Global Change Biol., 5, 755-770, 1999.

Gerten, D., Luo, Y., Le Maire, G., Parton, W. J., Keough, C., Weng, E., Beier, C., Ciais, P., Cramer, W., Dukes, J. S., Hanson, P. J., Knapp, A. A. K., Linder, S., Nepstad, D. A. N., Rustad, L., and Sowerby, A.: Modelled effects of precipitation on ecosystem carbon and water dynamics in different climatic zones, Global Change Biol., 14, 2365-2379, 2008.

Gielen, B., Verbeeck, H., Neirynck, J., Sampson, D. A., Vermeiren, F., and Janssens, I. A.: Decadal water balance of a temperate Scots pine forest (Pinus sylvestris L.) based on measurements and modelling, Biogeosciences, 7, 1247-1261, doi:10.5194/bg7-1247-2010, 2010.

Gilgen, A. K., Signarbieux, C., Feller, U., and Buchmann, N.: Competitive advantage of Rumex obtusifolius $\mathrm{L}$ might increase in intensively managed temperate grasslands under drier climate, Agr. Ecosyst. Environ., 135, 15-23, 2010.

Granier, A., Reichstein, M., Bréda, N., Janssens, I. A., Falge, E., Ciais, P., Grünwald, T., Aubinet, M., Berbigier, P., Bernhofer, C., Buchmann, N., Facini, O., Grassi, G., Heinesch, B., Ilvesniemi, H., Keronen, P., Knohl, A., Köstner, B., Lagergren, F., Lindroth, A., Longdoz, B., Loustau, D., Mateus, J., Montagnani, L., Nys, C., Moors, E. J., Papale, D., Peiffer, M., Pilegaard, K., Pita, G., Pumpanen, J., Rambal, S., Rebmann, C., Rodrigues, A., Seufert, G., Tenhunen, J., Vesala, T., and Wang, Q.: Evidence for soil water control on carbon and water dynamics in European forests during the extremely dry year: 2003, Agr. Forest Meteorol., 143, 123-145, 2007.

Hirschi, M., Seneviratne, S. I., Alexandrov, V., Boberg, F., Boroneant, C., Christensen, O. B., Formayer, H., Orlowsky, B., and Stepanek, P.: Observational evidence for soil-moisture impact on hot extremes in southeastern Europe, Nat. Geosci., 4, 17-21, 2011.

IPCC: Climate Change 2007: The Physical Science Basis. Contribution of Working Group I to the Fourth Assessment Report of the Intergovernmental Panel on Climate Change, edited by: Solomon, S., Qin, D., Manning, M., Chen, Z., Marquis, M., Averyt, K. B., Tignor, M., and Miller, H. L., Cambridge University Press, Cambridge, United Kingdom and New York, NY, USA, 2007

Jaeger, E. B. and Seneviratne, S. I.: The role of land-atmosphere coupling for European temperature and precipitation extremes and trends, Clim. Dynam. doi:10.1007/s00382-010-0780-8, 2010.

Jentsch, A., Kreyling, J., and Beierkuhnlein, C.: A new generation of climate change experiments: events, not trends, Front. Ecol. Environ., 5, 315-324, 2007.
Jones, H. G.: Plants and Microclimate: A Quantitative Approach to Environmental Plant Physiology, Cambridge: Cambridge University Press, UK, 2007.

Jung, M., Le Maire, G., Zaehle, S., Luyssaert, S., Vetter, M., Churkina, G., Ciais, P., Viovy, N., and Reichstein, M.: Assessing the ability of three land ecosystem models to simulate gross carbon uptake of forests from boreal to Mediterranean climate in Europe, Biogeosciences, 4, 647-656, doi:10.5194/bg-4-647-2007, 2007.

Kljun, N., Black, T. A., Griffis, T. J., Barr, A. G., Gaumont-Guay, D., Morgenstern, K., McCaughey, J. H., and Nesic, Z.: Response of net ecosystem productivity of three boreal forest stands to drought, Ecosystems, 9, 1128-1144, 2006.

Kimball, B. A.: Theory and performance of an infrared heater for ecosystem warming.,Global Change Biol., 11, 2041-2056, 2005.

Klok, E. J. and Klein Tank, A. M. G.: Updated and extended European dataset of daily climate observations, Int. J. Climatol., 29, 1182-1191, 2009.

Krinner, G., Viovy, N., de Noblet, N., Ogée, J., Friedlingstein, P., Ciais, P., Sitch, S., Polcher, J., and Prentice, I. C.: A dynamic global vegetation model for studies of the coupled atmospherebiosphere system, Global Biogeochem. Cy., 19, 1-33, 2005.

Larcher, W.: Physiological plant ecology, 4th edition, SpringerVerlag, Berlin, 2003.

Lucas, R. W., Forseth, I. N., and Casper, B. B.: Using rainout shelters to evaluate climate change effects on the demography of Cryptantha flava, J. Ecol., 96, 514-522, 2008.

Luo, Y., Gerten, D., Maire, G. L., Parton, W. J., Weng, E., Zhou, X., Keough, C., Beier, C., Ciais, P., Cramer, W., Dukes, J. S., Emmett, B., Hanson, P. J., Knapp, A., Linder, S., Nepstad, D., and Rustad, L.: Modeled interactive effects of precipitation, temperature, and $\mathrm{CO}_{2}$ on ecosystem carbon and water dynamics in different climatic zones, Global Change Biol., 14, 1986-1999, 2008.

Meehl, G. A. and Tebaldi, C.: More Intense, More Frequent, and Longer Lasting Heat Waves in the 21st Century, Science, 305, 994-997, 2004.

Padilla, F. M. and Pugnaire, F. I.: Rooting depth and soil moisture control Mediterranean woody seedling survival during drought, Funct. Ecol., 21, 489-495, 2007.

Pfisterer, A. B., and Schmid, B.: Diversity-dependent production can decrease the stability of ecosystem functioning, Nature, 416 , 84-86, 2002.

Piao, S., Ciais, P., Friedlingstein, P., Peylin, P., Reichstein, M., Luyssaert, S., Margolis, H., Fang, J., Barr, A., Chen, A., Grelle, A., Hollinger, D. Y., Laurila, T., Lindroth, A., Richardson, A. D., and Vesala, T.: Net carbon dioxide losses of northern ecosystems in response to autumn warming, Nature, 451, 49-53, 2008.

Reichstein, M., Ciais, P., Papale, D., Valentini, R., Running, S., Viovy, N., Cramer, W., Granier, A., Ogée, J., Allard, V., Aubinet, M., Bernhofer, C., Buchmann, N., Carrara, A., Grünwald, T., Heimann, M., Heinesch, B., Knohl, A., Kutsch, W., Loustau, D., Manca, G., Matteucci, G., Miglietta, F., Ourcival, J. M., Pilegaard, K., Pumpanen, J., Rambal, S., Schaphoff, S., Seufert, G., Soussana, J. F., Sanz, M. J., Vesala, T., and Zhao, M.: Reduction of ecosystem productivity and respiration during the European summer 2003 climate anomaly: a joint flux tower, remote sensing and modelling analysis, Global Change Biol., 13, 634-651, 2007. 
Santaren, D., Peylin, P., Viovy, N., and Ciais, P.: Optimizing a process-based ecosystem model with eddy-covariance flux measurements: A pine forest in southern France, Global Biogeochem. Cy., 21, GB2013, doi:10.1029/2006GB002834, 2007.

Schär, C., and Jendritzky, G.: Hot news from summer 2003, Nature, 432, 559-560, 2004.

Schär, C., Vidale, P. L., Lüthi, D., Frei, C., Häberli, C., Liniger, M., and Appenzeller, C.: The role of increasing temperature variability in European summer heatwaves, Nature, 427, 332-336, 2004.

Schwalm, C. R., Williams, C. A., Schaefer, K., Anderson, R., Arain, M. A., Baker, I., Barr, A., Black, T. A., Chen, G., Chen, J. M., Ciais, P., Davis, K. J., Desai, A., Dietze, M., Dragoni, D., Fischer, M. L., Flanagan, L. B., Grant, R., Gu, L., Hollinger, D., Izaurralde, R. C., Kucharik, C., Lafleur, P., Law, B. E., Li, L., Li, Z., Liu, S., Lokupitiya, E., Luo, Y., Ma, S., Margolis, H., Matamala, R., McCaughey, H., Monson, R. K., Oechel, W. C., Peng, C., Poulter, B., Price, D. T., Riciutto, D. M., Riley, W., Sahoo; A. K., Sprintsin, M., Sun, J., Tian, H., Tonitto, C., Verbeeck, H., and Verma, S. B.: A model-data intercomparison of $\mathrm{CO}_{2}$ exchange across North America: Results from the North American Carbon Program site synthesis, J. Geophys. Res., 115, G00H05, doi:10.1029/2009JG001229, 2010.

Serinaldi, F., Bonaccorso, B., Cancelliere, A., and Grimaldi, S.: Probabilistic characterization of drought properties through copulas, Phys. Chem. Earth, 34, 596-605, 2009.

Svejcar, T., Angell, R., and Miller, R.: Fixed location rain shelters for studying precipitation effects on rangelands, J. Arid Environ., 42, 187-193, 1999.

Teuling, A. J., Seneviratne, S. I., Stöckli, R., Reichstein, M., Moors, E., Ciais, P., Luyssaert, S., van den Hurk, B., Ammann, C., Bernhofer, C., Dellwik, E., Gianelle, D., Gielen, B., Grünwald, T., Klumpp, K., Montagnani, L., Moureaux, C., Sottocornola, M., and Wohlfahrt, G.: Contrasting response of European forest and grassland energy exchange to heatwaves, Nat. Geosci., 3, 722$727,2010$.
Trenberth, K. E. and Shea, D. J.: Relationships between precipitation and surface temperature, Geophys. Res. Lett., 32, L14703, doi:10.1029/2005GL022760, 2005.

Vandentorren, S., Suzan, F., Medina, S., Pascal, M., Maulpoix, A., Cohen, J. C., Ledrans, M.: Mortality in 13 French cities during the August 2003 heat wave, Am. J. Public Health, 94, 15181520, 2004.

Vautard, R., Yiou, P., D’Andrea, F., de Noblet, N., Viovy, N., Cassou, C., Polcher, J., Ciais, P., Kageyama, M., and Fan, Y.: Summertime European heat and drought waves induced by wintertime Mediterranean rainfall deficit, Geophys. Res. Lett., 34, L07711, doi:10.1029/2006GL028001, 2007.

Verbeeck, H., Steppe, K., Nadezhdina, N., Op De Beeck, M., Deckmyn, G., Meiresonne, L., Lemeur, R., Čermák, J., Ceulemans, R., and Janssens, I. A.: Model analysis of the effects of atmospheric drivers on storage water use in Scots pine, Biogeosciences, 4, 657-671, doi:10.5194/bg-4-657-2007, 2007.

Verbeeck, H., Peylin, P., Bacour, C., Bonal, D., Steppe, K., and Ciais P.: Seasonal patterns of $\mathrm{CO}_{2}$ fluxes in Amazon forests: fusion of eddy covariance data and the ORCHIDEE model, J. Geophys. Res., doi:10.1029/2010JG001544, 2011.

Vetter, M., Churkina, G., Jung, M., Reichstein, M., Zaehle, S., Bondeau, A., Chen, Y., Ciais, P., Feser, F., Freibauer, A., Geyer, R., Jones, C., Papale, D., Tenhunen, J., Tomelleri, E., Trusilova, K., Viovy, N., and Heimann, M.: Analyzing the causes and spatial pattern of the European 2003 carbon flux anomaly using seven models, Biogeosciences, 5, 561-583, doi:10.5194/bg-5561-2008, 2008.

Yang, J., Zhang, J., Huang, Z., Zhu, Q., and Wang, L.: Remobilization of Carbon Reserves Is Improved by Controlled Soil-Drying during Grain Filling of Wheat, Crop Sci., 40, 1645-1655, 2000.

Zeng, X.: Global vegetation root distribution for land modeling, J. Hydrometeorol., 2, 525-530, 2001. 